\title{
TACSTD2 wt Allele
}

National Cancer Institute

\section{Source}

National Cancer Institute. TACSTD2 wt Allele. NCI Thesaurus. Code C52232.

Human TACST D2 wild-type allele is located within 1p32-p31 and is approximately $3 \mathrm{~kb}$ in length. This allele, which encodes tumor-associated calcium signal transducer 2 protein, is involved in intracellular calcium signal transduction. Mutations of the gene result in gelatinous drop-like corneal dystrophy. 